\title{
Leveraging the economical benefits of sustainable building
}

\author{
A. van Hal \\ Delft University of Technology, The Netherlands
}

\begin{abstract}
In 2004, the Dutch National Sustainable Building Centre performed a research project to investigate the general belief that sustainable building is more expensive than standard building practice. The results, based on literature study and interviews, proved this to be untrue and demonstrated sustainable building to be economically very similar to standard practice or sometimes even better. The research project also showed that these positive financial aspects are hardly ever used to promote sustainable building. This seems to be due to a lack of knowledge on the part of construction companies, the unfavorable image of sustainable building and several institutional impediments. For example the typical split accountabilities of the investment budget on the one hand and the maintenance budget on the other hand, drives many ecologically suboptimal decisions.

Initiated by SenterNovem [1] a new research project was started to recommend practical solutions to these identified issues. Besides the sustainable and "regular" building sectors, other sectors were investigated to develop new insights. For example the experiences of companies experimenting with corporate social responsibility were included in the scope of the project, which was finalized in March 2006. The paper describes in detail the key conclusions and recommendations from this research.

Keywords: economical benefit, profit, sustainable building, corporate social responsibility, innovation, incentives, labeling system, green mortgage, tax, real estate broke.
\end{abstract}

\section{Objective, scope and research design}

In 2004, the Dutch National Sustainable Building Centre (now part of SenterNovem) performed a research project to investigate the profitability of 
sustainable building [2]. The results proved that sustainable building can be profitable but is rarely put into practice due to various (institutional) obstacles. At the end of 2005 further research was started. The objective was to generate practical solutions to improve the chances of profit. The research focused on both housing and public buildings and was carried out in ten weeks.

\subsection{Scope}

Sustainable building can be interpreted as corporate social responsibility (csr) in building related companies. Like in all other sectors of industry csr-activities are related to one of five csr-typologies [3]:

1. as a form of charity, without any relation with the core-business

2. as the special interest of one of the employees

3. as civic duty of the company

4. as a motivator, based on profits other than financial (for example a better image or a better relationship with the government)

5. as a motivator, based on financial profit. In this case csr is part of the core business of the company.

The research is focused on typology 4 and 5 .

\subsection{Research design}

The research design encloses interviews, a study of literature and a workshop.

\subsubsection{Interviews}

During the research of 2004 many people involved in sustainable building in the Netherlands already were interviewed on the subject. For this reason and to get new and inspiring information, not only sustainable building specialists were approached but also other people within the construction industry and people active in csr in other industries. In total ten persons were interviewed.

\subsubsection{A study of literature}

The study of literature started with reports of recent research related to financial profit and sustainable building. Also literature recommended by the people interviewed was studied such as international books about the profit of sustainable building and csr.

\subsubsection{Workshop}

The results of the interviews and literature study were discussed during a workshop with representatives of different professional groups related to sustainable building. Present were representatives of the state [4], a municipality, the insulation industry, a bank, a real estate broker, a building company, a housing corporation, a consultancy and SenterNovem. 


\section{Results of interviews and study of literature}

This chapter describes the results of the interviews and literature study in three paragraphs; preconditions, parties involved and incentives.

\subsection{Preconditions}

A precondition is no action but a condition that in general leverages the economical benefits of sustainable building. The interviews and literature study resulted in 41 preconditions. Based on the research results it's impossible to order these preconditions by priority. However, one precondition was named and written about very often and for that reason this specific precondition will be described underneath.

\subsubsection{Linking sustainability with innovations}

Innovations seem to be the carrier for sustainability in the near future. It is not without reason that the innovation platform of the government - Dutch Prime Minister Balkenende is chair - recently chose sustainability as one of the leading objectives. Many of the largest Dutch housing developers and building companies are very innovative at the moment. These innovations are not only technical but also financial (new financial constructions), related to services (from building only to building and maintenance, energy supply etc.), related to the scale of work (from building to built environment) and to the process (more interdisciplinary and goal related, more cooperation).

\subsection{Parties involved}

Parties involved are the professional groups, which can positively influence the economical benefits of sustainable building. In alphabetical order the following parties came out of the interviews and literature study:

- Architects

- Banks

- Business organizations

- Clients, like the CEO's of companies building their new office, CEO's of hospitals, etc.

- Constructors

- Consultants

- Consumers

- Housing corporations

- Institutes issuing permits

- Insurance companies

- Local authorities

- National Government

- NGO's

- Project developers

- Public utilities

- Real Estate Brokers

- Supply companies 


\subsection{Incentives}

Incentives are activities that leverage the economical benefits of sustainable building. The research resulted in 90 incentives. During the workshop the number of incentives was reduced to the 8 most important ones (see chapter 3 ). The long list of incentives would only lead to the conclusion that there is no single activity to reach the goal. To leverage the economical benefits of sustainable building a chain of activities has to start. All activities have to be related which makes cooperation necessary.

\section{Results of the workshop}

The workshop was very important for the result of the research. During one afternoon the long list of 90 incentives was reduced and translated into a practical approach based on related activities.

Quite simply the long list of incentives was reduced. By sticking every incentive in an empty matrix (see figure 1) priority was given to almost $50 \%$ of the incentives. These were the incentives, which were placed at the upper half of the matrix.

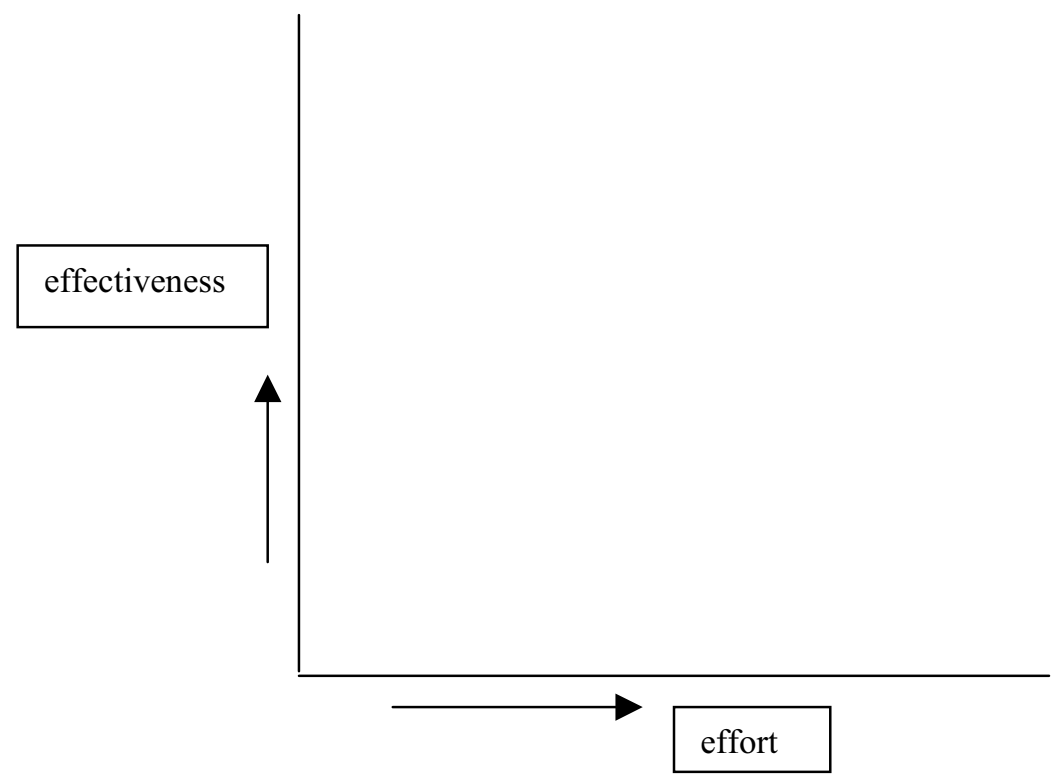

Figure 1: $\quad$ Matrix.

In a second round each participant chose his/her personal ten most promising incentives. The count of 'the votes' resulted in eight incentives to focus on. 
These were:

- $\quad$ leveraging the benefits of the (already existing) green mortgage

- the accelerated introduction of an overall quality test for housing

- (re)introducing an energy performance certificate for existing housing and buildings

- $\quad$ improving the existing green funding system of banks

- $\quad$ improving the knowledge exchange by real estate brokers

- cooperation in (innovative) product development

- developing affordable and green innovative housing concepts (for the new and existing stock)

- leveraging green prefabrication

Next, two groups of participants debated about practical conditions related to these eight incentives. Each group focused on four incentives but they were allowed to relate those to other incentives. The result was very surprising; the conclusions were both adjoining and supplementary. As a result the research could be finished with a practical approach based on related activities.

\section{Conclusion}

The objective of the research was to leverage the economical benefits of sustainable building by generating practical solutions. The result of this research is a proposal for a practical approach based on related activities. However; the result is focused only on housing while the research was focused on housing and public buildings. Reason for this difference is the fact that the participants who represented public buildings were, at the last minute, unable to attend the workshop.

\subsection{Stepping-stone}

In the workshop both groups of participants introduced the same stepping-stone for all the financial incentives. Both groups were convinced of the fact that the introduction of a labeling system that covers all activities ("one language") is inevitable. For that reason highest priority goes to the introduction of a labeling system that translates sustainability in housing into a manageable and controllable system. The system should show in a very accessible way the level of sustainability of a specific house. To get this system introduced in the consumer world a clear relation with consumer needs is necessary. For example: instead of using environmental language with topics as energy, water and waste consumer language including terminology such as moneysaving, flexibility and health should be preferred.

This labeling system could be initiated by the market (voluntary) or by the state government (compulsory). The state government should act in the public interest and for that reason initiative by the government seems logical. If labeling were compulsory, sustainable building could become an integrated aspect of the financial overview instead of an (expensive) 'extra'. However, involvement of the government very often slows down the process. 'The market' also benefits 
from the introduction of a labeling system and for that reason a quick market initiative, ahead of a government initiative, is preferable.

\subsection{Related incentives}

The selected incentives could all be related to this labeling system as are some other incentives of the long list. Not all of these incentives are directly related to financial profit. However; if they result in an increasing choice for sustainable housing and building products the prices of the product will be reduced as a result of market mechanisms.

\subsubsection{An overall quality test for housing}

The introduction of an overall quality test for housing in the Netherlands has been a point of discussion for years. It is very logical to integrate a sustainable housing labeling system into an overall quality mark for housing. In this way sustainability in housing becomes natural.

This overall quality system should be performance based (as should be the sustainable building labeling system) and attractive to do-it-your-self craftsmen and tenants and renters.

\subsubsection{Green mortgage}

It is logical to link the labeling system with existing financial constructions like the Green Mortgage (has to be improved to become more effective) and the recently introduced Climate Mortgage. This Climate Mortgage relates energy saving to the interest of the mortgage.

\subsection{3 (Property) tax}

The labeling system could also be related to the property tax or other taxes. A proven sustainable quality of the house could lead to lower taxes.

\subsubsection{Integration in the Funda-system}

The award winning Funda.nl website is the main resource for people seeking a house in the Netherlands. Funda brings together housing stock supplied by members of the Netherlands association of real estate brokers (NVM) and independently-sourced neighborhood information. If the labeling system in its most elementary form is integrated in the Funda-system, real estate brokers are forced to know more about sustainability. NVM already started courses in this field. These courses combined with accessibly written fact sheets should inform real estate brokers in an effective way.

\subsubsection{Private law agreements}

Private law agreements can improve the level of sustainability of new housing and renovation of the existing stock. The labeling system can form the basis for these agreements. If developers are pressed by a municipality to sign agreements in this field the municipality itself should do something against extreme high land prices (a real problem for developers in the Netherlands). 


\subsubsection{Competition}

The labeling system can also lay down the criterion for housing competitions among developers. Limiting the amount of participants and compensation for the 'good' losers can directly and indirectly result in cost-effectiveness. The compensation could be some $\mathrm{CO} 2$-points. The amount of $\mathrm{CO} 2$-points will increase the chance to be invited for a competition.

\subsubsection{Developing affordable and green innovative housing concepts}

A labeling system can also further the development of affordable and green innovative housing concepts for the new and existing housing stock. Cooperation between all related professional parties is necessary. For example, in the form of a consortium.

\subsubsection{Green rebuild fund}

A labeling system can also further the sustainable renovation of private houses. However, the high investment is the main obstacle. To use the existing Green Fund for loans for private home-owners who want to rebuild sustainable a Green Rebuild Fund arises. This also furthers the cooperation with banks.

\subsubsection{Rebuild shop}

Recently a rebuild-shop started in the Netherlands. A shop where home-owners can get all the information, products and help related to rebuilding and renovation. The labeling system can further the integration of sustainability into this concept.

\section{References}

[1] SenterNovem is an agency of the Dutch Ministry of Economic Affairs for implementing policies on innovation, energy and climate and environment and spatial planning (www.senternovem.nl). The report of the research is called 'Praktische prikkels, een voorstel ter vergroting van de rentabiliteit van duurzaam bouwen". (Anke van Hal, maart 2006)

[2] Nationaal Dubocentrum, Eindrapportage onderzoek financieel rendement duurzaam bouwen, september 2004

[3] MVO, MVO Nederland in beweging, Het maatschappelijk verslag 2004

[4] Among the workshop participants were representatives of the Ministry of Economic Affairs and the Ministry of Housing, Spatial Planning and the Environment. However, the results of the workshop do not as a matter of course represent the view of these Ministries. 